\title{
PENGARUH GREEN ACCOUNTING TERHADAP MFCA DALAM MENINGKATKAN KEBERLANGSUNGAN USAHA SERTA RESOURCE EFFICIENCY SEBAGAI 33 VARIABEL MODERATING (STUDI KASUS PADA PERUSAHAAN PERAIH PENGHARGAAN HIJAU YANG LISTING DI JAKARTA ISLAMIC INDEX)
}

\author{
Windasari Rachmawati'; Abdul Karim² \\ Fakultas Ekonomi Universitas Semarang1,2 \\ windasarirachmawati@usm.ac.id ${ }^{1}$; abdulkarim.akt@gmail.com
}

\begin{abstract}
ABSTRAK
Penggunaan kalimat green accounting akhir - akhir ini mulai populer dengan semakin meningkatnya penelitian yang mengangkat green accounting di Indonesia. Green accounting berhubungan dengan informasi lingkungan dan pengauditan pada lingkungan yang memiliki definisi sebagai suatu identifikasi, penyelidikan,analisis serta pelaporan dan informasi biaya yang beerhubungan dengan bidang lingkungan dari suatu organisasi. Fungsi utama green accounting untuk mengatasi masalah lingkungan sosial, serta memiliki dampak pada pencapaian pembangunan yang berkelanjutan beserta lingkungannya. Hal ini mempengaruhi perilaku perusahaan dalam menghadapi isu - isu tanggung jawab sosial dengan lingkungannya. MFCA sebagai alat kunci dari pendekatan manajemen yaitu flow managementt yang memiliki tujuan khusus mengelola proses manufaktur yang berhubungan dengan aliran material, energi, dan data. Penelitian ini menggunakan alat uji statistic dengan uji moderasi yang diperoleh hasil bahwa Matterial flow cost accounting di ukur dari biaya produksi,luas area produksi, dan hasil atau nilai produksi, terhadap keberlangsungan usaha, dan green accounting tidak berpengaruh terhadap keberlangsungan usaha.

Kata Kunci: Green accounting, Jakarta islamic index, material flow cost accounting and resource efficiency
\end{abstract}

\section{Abstract}

The use of the term green accounting has recently become popular with the increasing number of researches that raise green accounting in Indonesia. Green accounting deals with environmental information and environmental auditing systems and has been defined as' the identification, tracking, analysis, and reporting and cost information related to environmental aspects of an organization. The main role of green accounting is to address social environmental problems, as well as to have an impact on the achievement of sustainable development and the environment in any country, which affects corporate behavior in dealing with issues of social and environmental responsibility. MFCA is a key tool in a management approach known as flow management which aims specifically at managing manufacturing processes related to the flow of materials, energy and data. This study uses a statistical test tool with a moderation test, which shows that material flow cost accounting is measured from the cost of production, the area of production and the yield or value of production on business continuity, and green accounting has no effect on business continuity.

Keywords: Green accounting, Jakarta Islamic index, material flow cost accounting, resource efficiency

Diterima: 30 Maret 2021; Direvisi: 6 April 2021; Diterbitkan: 20 April 2021 


\section{PENDAHULUAN}

Green accounting berhubungan dengan informasi lingkungan dan sistem audit lingkungan yang telah di definisikan sebagai suatu identifikasi, pelacakan, analisis, serta pelaporan dan informasi biaya yang terkait dengan suatu aspek lingkungan dari suatu organisasi. Fungsi utama daripada green accounting adalah untuk mengatasi masalah lingkungan sosial, dengan memiliki akibat pada pencapaian pembangunan berkelanjutan dan lingkungan di negara manapun, yang berpengaruh pada perilaku perusahaan dalam menghadapi isu - isu tanggung jawab sosial pada lingkungannya. Green accounting juga dipakai sebagai upaya perusahaan untuk membantu dalam mencapai tujuan perusahaan terhadap tanggung jawab pada stake holder.

Menurut Bebbington (1997) Konsep green accounting sudah mulai dilakukan penelitian pada tahun 1980-an. Standar industri semakin berkembang dan auditor profesional seperti The American Institute of Certified Public Auditors (AICPA) menerbitkan prinsip universal tentang audit lingkungan. pada negara - negara maju sudah banyak dikeluarkan peraturan tentang lingkungan.

Indonesia mengeluarkan peraturan terkait dengan lingkungan hidup pada UU RI No. 32 tahun 2009 tentang perlindungan dan lingkungan hidup. Pada dasarnya green accounting menjadi sesuatu yang penting karena berkaitan dengan penyampaian informasi mengenai aktivitas sosial dan perlindungan terhadap lingkungan kepada stakeholder perusahaan. Perusahaan tidak hanya memberikan informasi mengenai keuangan kepada investor dan kreditor yang telah ada, tetapi juga calon investor dan kreditor perusahaan. Akan tetapi juga harus memperhatikan kepentingan sosial dimana perusahaan beroperasi. Berita yang negatif secara otomatis langsung bisa menyebar dan mudah di akses.

Menurut kusumaningtias (2013) green accounting merupakan upaya perusahaan untuk menghubungkan kepentingan ekonomi dengan pelestarian lingkunga. Green accounting sebagai kombinasi manfaat lingkungan dan biaya dalam pengambilan keputusan. Green accounting dipengaruhi dan mempengaruhi dimana perusahaan itu berdiri. Menurut Fakoya (2014) Proses produksi suatu barang mulai dari pengambilan bahan baku sampai ke pembuangan suatu produk setelah dikonsumsi (digunakan) tidak merusak lingkungan apalagi jika perusahaan bisa merinci biaya lingkungan tersebut. Sedangakn menurut Descalu (2010) Setidaknya perusahaan tidak membuat sama biaya - biaya tidak langsung termasuk biaya lingkungan ke dalam biaya overhead sehingga terselubung dan manajer kesulitan untuk mencari informasi dan melakukan pengendalian biaya.

Usaha dalam masalah pengurangan limbah dari pandangan yang berbeda, akuntansi manajemen kontemporer mengembangkan akuntansi manajemen kontemporer mengembangkan alat pengumpulan untuk kuantifikasi limbah tertentu, yaitu Material Flow Cost Accounting (MFCA) sebagai informasi secara keuangan dan non keuangan dalam rangakaian mendukung keputusan pengurangan limbah oleh para manajer. Hal 
ini terkait dengan biaya lingkungan seperti pengolahan limbah, pembuangan limbah dan pembangunan instalasi. Penelitian leon (2018) mengatakan bahwa material flow cost accounting memiliki pengaruh positif terhadap green accounting yang diperkuat oleh resource efficiency yang diukur dari: 1) kekuatan keuangan, 2) kemampuan produksi dan fleksibilitas 3) kekuatan pemasaran. Sedangkan penelitian Nakajima, Kimura, dan Wangner (2014) menyatakan pentingnya kesadaran akan lingkungan, karena akan berpengaruh pada efisiensi sumber daya dalam kerangka kerja.

Penelitian Marota (2017) material flow cost accounting atau sering disebut MFCA yang menggunakan biaya produksi, luas area pabrik produksi dan nilai atau hasil produksi sebagai variabel dalam MFCA, menunjukkan bahwa MFCA berpengaruh positif pada keberlangsunganperusahaan.Berdasarkan studi pendahuluan yang telah dilakukan dengan pendekatan dari berbagai kajian teori dan penelitian yang telah dilakukan, maka penelitian yang akan dilakukan dalam menganalisis pengaruh MFCA terhadap keberlangsungan usaha dengan variabel resource efficiency sebagai variabel moderating (studi kasus pada perusahaan industri hijau di jii) adalah menggali permasalahan yang muncul dalam upaya perusahaan meningkatkan keberlanjutan usaha.

\section{Rumusan Masalah}

1. Apakah MFCA (biaya produksi) berpengaruh dalam meningkatkan keberlangsungan usaha?

2. Apakah MFCA (luas area pabrik produksi) berpengaruh dalam meningkatkan keberlangsungan usaha?
3. Apakah MFCA (hasil atau nilai produksi) berpengaruh dalam meningkatkan keberlangsungan usaha?

4. Apakah konsep green accounting berpengaruh dalam meningkatkan keberlangsungan usaha?

5. Apakah resource efficiency memperkuat MFCA terhadap keberlangsungan usaha

6. Apakah resource efficieny memperkuat implementasi green accounting terhadap keberlanjutan usaha?

\section{LANDASAN TEORI}

Stakeholder theory merupakan salah satu teori utama yang banyak digunakan untuk stakeholder eksternal yang terdiri dari pemerintah, masyarakat, lingkungan dan pemangku kepentingan masa depan (Hernadi, 2012). Sedangkan yang termasuk ke dalam stakeholder sekunder adalah media dan pihak-pihak yang berkepentingan dengan cakupan yang lebih luas (Cohen et al., 2009). Hubungan perusahaan dengan stake holder dibangun berdasarkan konsep kebermanfaatan yang membangun kerjasama untuk bisa membangun kesinambungan usaha perusahaan. Mengabaikan kepentingan para pemangku kepentingan dapat mencemari citra publik perusahaan, yang tidak baik akan mempengaruhi kinerja keuangan perusahaan.

Stakeholder memiliki harapan yang berbeda-beda terhadap perusahaan, untuk mengejar harapan tersebut stakeholder dapat memberikan tekanan kepada perusahaan secara langsung maupun tidak langsung dalam melakukan pengungkapan lingkungan 
(Ghomi dan Leung,2013). Munculnya teori stakeholders sebagai paradigma dominan semakin menguatkan konsep bahwa perusahaan bertanggung jawab tidak hanya kepada pemegang saham melainkan juga terhadap para pemangku kepentingan atau stakeholder (Maulida dan Adam, 2012).

\section{Legitimacy Theory}

Legitimacy theory menurut Lindawati dan Puspita (2015) legitimasi dari stakeholders sangat penting bagi perusahaan karena dengan adanya legitimacy gap memiliki potensi besar terjadinya protes dari stakeholders terhadap perusahaan yang berdampak pada eksistensi perusahaan dan mengganggu stabilitas operasional dan berakhir pada profitabilitas. Menurut Tarigan dan samuel (2014) Legitimasi dari masyarakat adalah sumber daya operasional yang paling penting bagi perusahaan karena hal ini terkait dengan going concern (keberlangsungan perusahaan). Pendekatan legitimasi dalam green accounting terkait keberlangsungan suatu entitas, dalam hal ini dapat dikatakan sebagai bentuk upaya untuk memberikan transparansi informasi yang diungkapkan tidak hanya berupa informasi keuangan perusahaan saja, tetapi perusahaan juga diharapkan mengungkap- kan informasi mengenai dampak-dampak sosial dan lingkungan hidup yang diakibat- kan oleh aktivitasaktivitas perusahaan.

\section{Green Accounting}

Green accounting menurut Aniela (2012) merupakan akuntansi yang di dalamnya mengidentifikasi, mengukur, menilai, dan mengungkapkan biayabiaya terkait dengan aktivitas perusahaan yang berhubungan dengan lingkungan.
Sedangkan menurut amiruddin (2012) Green accounting merupakan penggabungan informasi manfaat dan biaya lingkungan kedalam macammacam praktik akuntansi dan penggabungan biaya lingkungan kedalam keputusan bisnis. Pelaksanaan green accounting sangat bergantung kepada karakteristik perusahaan tersebut dalam memahami permasalahan lingkungan hidup. Pemahaman mengenai permasalahan lingkungan hidup akan mengarahkan perusahaan ke dalam kebijakan terutama terkait lingkungan hidup.

green $\begin{array}{cc}\text { Tujuan dikembangkannya } \\ \text { accounting yaitu untuk }\end{array}$ mendorong pertanggung jawaban perusahaan dan meningkatkan transparansi lingkungan, membantu entitas dalam menetapkan strategi untuk menanggapi isu lingkungan hidup dalam konteks hubungan entitas dengan masyarakat dan terlebih dengan kelompok-kelompok penggiat (activist) atau penekan (pressure group) terkait isu lingkungan, memberikan citra yang lebih positif sehingga entitas dapat memperoleh dana dari kelompok dan individu "hijau", seiring dengan tuntutan etis dari investor yang semakin meningkat, mendorong konsumen untuk membeli produk hijau sehingga entitas memiliki keunggulan pemasaran yang lebih kompetitif dibandingkan entitas yang tidak melakukan pengungkapan, menunjukkan komitmen entitas terhadap usaha perbaikan lingkungan hidup, mencegah opini negatif publik mengingat perusahaan yang berusaha pada area yang berisiko tidak ramah lingkungan pada umumnya akan menerima tantangan dari masyarakat mendasari penelitian tentang keberlanjutan usaha. Stakeholder dibagi menjadi dua, yaitu stakeholder internal 
yang terdiri dari pemilik, manajemen, dan karyawan.

\section{Material Flow Cost Accounting}

MFCA merupakan alat kunci dari pendekatan manajemen disebut sebagai flow management yang bertujuan secara khusus untuk mengelola proses manufaktur yang berkaitan dengan aliran material, energi, dan data sehingga proses manufaktur dapat lebih efisien dan sesuai dengan target yang ditetapkan (Hyrslova et al., 2011, Viere et al., 2011, Jasch 2009). MFCA bisa digunakan disemua jenis industri yang menggunakan bahan baku dan energi, semua jenis dan ukuran, dengan atau tanpa tempat sistem pengelolaan lingku ngan. Konsep utama MFCA didasarkan pada masukan (bahan, energi, air, dan input lainnya) dan keluaran (produk utama atau produk sampingan, limbah, limbah cair, emisi) ditentukan dalam pusat kuantitas, dan perhitungan dilakukan sehubungan dengan biaya material, energi, dan sistem yang dikeluarkan untuk produk dan kerugian material.

Menurut machmoedi (2017) Dalam upaya perusahaan untuk berkontribusi pada masalah pengurangan limbah, terdapat beberapa pendekatan pengelolaan limbah dan pemanfaatan bahan baku dari sumber limbah diantaranya adalah dengan mengunakan analisis pinch, pengembangan model matematika untuk pengelolaan bahan baku dan produk, sintesis pertukaran jaringan masa reaktif, dan metode grafis untuk pembuangan limbah

\section{Keberlangsungan usaha}

Bare (2011) mengungkapkan bahwa terdapat lima elemen bagi organisasi perusahaan dalam pengembangan lingkungan yang berkelanjutan yaitu keberlanjutan dalam ekonomi, indikator sosial, analisis lingkungan, indikator keberlanjutan yang diseleksi secara independen serta material dan sumber daya yang digunakan. Menurut lynch (2011) Keberlanjutan suatu perusahaan menjadi faktor pengembangan untuk memenuhi kebutuhan saat ini tanpa mengorbankan kemampuan dimasa yang akan datang untuk memenuhi kebutuhannya itu sendiri. Keberlangsungan hidup suatu perusahaan bergantung pada keuntungan (profit) yang diperolehnya. Keuntungan inilah yang kemudian menjadi tujuan utama didirikannya suatu perusahaan. (Soehardi \& Untari, 2020).

Pengaruh Material Flow Cost Accounting (biaya produksi) dalam Meningkatkan Keberlangsungan Perusahaan

Perusahaan selalu memiliki masalah dalam persaingan harus selalu melakukan inovasi dalam mutu barang dan layanan serta efisiensi dalam menekan biaya produksi sehingga harga penjualan produk tetap dapat bersaing (Putranto, 2017). Maka hipotesis pertama yang diajukan:

$\mathrm{H}_{1}$ : MFCA (biaya produksi) berpengaruh dalam meningkatkan keberlangsungan perusahaan

\section{Pengaruh MFCA (Luas Area Pabrik Produksi) dalam Meningkatkan Keberlangsungan Usaha}

Penelitian Marota et al. (2015) yang meneliti tentang perancangan dan penerapan MFCA untuk meningkatkan 
keberlanjutan perusahaan. Hasilnya menunjukkan bahwa pengaruh yang signifikan antara penerapan MFCA dan keberlanjutan usaha.

$\mathrm{H}_{2}$ : MFCA (luas area pabrik produksi) berpengaruh dalam meningkatkan keberlangsungan perusahaan

\section{Pengaruh MFCA (Hasil atau Nilai Produksi) dalam Meningkatkan Keberlangsungan Usaha}

Hasil Penelitian Putra (2012) nilai produksi terhadap penyerapan tenaga kerja pada industri mebel di Kecamatan Pedurungan Kota Semarang menunjukkan bahwa ada pengaruh terhadap penyerapan tenaga kerja pada industri mebel di Kecamatan Pedurungan Kota Semarang. $\mathrm{H}_{3}$ : MFCA (Hasil atau Nilai Produksi) Berpengaruh Meningkatkan usaha

\section{Pengaruh Green accounting dalam Meningkatkan Keberlangsungan Usaha}

\section{Dalam hal ini Implementasi} Green Accounting memberi perhatian penuh pada konsep penghematan, yaitu penghematan lahan, penghematan bahan, dan penghematan energi (saving land, saving material, and saving energy). Menurut Loen (2018) Secara singkat, Implementasi Green Accounting dapat memberikan informasi mengenai sejauh mana organisasi atau perusahaan memberikan kontribusi positif maupun negatif terhadap kualitas hidup manusia dan lingkungannya.

H4: Green accounting berpengaruh positif terhadap keberlangsungan perusahaan.

\section{Resource Efficiency}

Resource efficiency adalah suatu nilai yang dimiliki oleh materi atau unsur tertentu dalam kehidupan yang diolah secara minimum untuk mendapatkan hasil maksimum. Sumber daya tidak selalu fisik tetapi juga non fisik. Penelitian ini ingin meneliti efisiensi sumber daya dilihat dari kekuatan keuangan, karena diperlukan permodalan yang besar untuk memulai suatu jenis usaha, termasuk penelitian dan pengembangan termasuk penelitian pemasaran, fasilitas produksi dan periklanan.

Menurut nakajima, kimura dan wagner (2014) pada saat memperkenalkan MFCA ke rantai suppy dengan tujuan membangun supply chain rendah karbon dan meningkatnya isu isu lingkungan maka kerangka kerja juga ikut terbentuk dan efisiensi sumber daya juga terbentuk.

H5: RE memperkuat MFCA terhadap keberlangsungan usaha

Sedangkan menurut mont (2002) sistem layanan produk yang sukses memerlukan infrastruktur masyarakat, struktur manusia dan tata letak organisasi yang berbeda agar bisa berkelanjutan

H6: RE memperkuat dampak green accounting keberlangsungan usaha

\section{Penelitian Terdahulu Yang Relevan}

Wahyudin (2017) dalam
penelitiannya mengungkapkan Biaya
produksi memiliki pengaruhpositif
terhadap keberlangsungan perusahaan.
Perusahaan yang mengeluarkan biaya
produksi memiliki target atau tujuan
untuk dicapai, salah satu tujuan tersebut


adalah untuk mendapatkan hasil yang diinginkan dengan meminimalkan pengeluaran biaya- biaya yang terjadi dalam proses produksi serta dapat meningkatkan keberlangsungan perusahaan. Komponen Luas area pabrik produksi tidak berpengaruh dalam meningkatkan keberlangsungan perusahaan. Perusahaan yang memiliki luas area pabrik tidak menjamin untuk meningkatkan keberlangsungan suatu perusahaan apabila tata letak pabrik atau tata cara pengaturan fasilitas-fasilitas pabrik tidak sesuai atau tidak strategis bagi perusahaan.

Sedangkan menurut yohannes (2018) kinerja lingkungan berpengaruh positif pada kinerja keuangan. Temuan ini mampu membuktikan teori legitimasi sebagai landasan yang menjelaskan pengaruh kinerja lingkungan pada kinerja keuangan. Perusahaan harus menyelaraskan tujuan ekonomi dengan tujuan lingkungan dan sosialnya. Apabila perusahaan menginginkan kinerja keuangan perusahaan meningkat, maka perusahaan harus mampu meningkatkan kinerja lingkungannya karena masyarakat selaku konsumen akan menaruh kepercayaannya pada legitimasi tersebut.

\section{Corporate Social Responsibility} Disclosure berpengaruh positif pada kinerja keuangan perusahaan. Pengungkapan ini dipandang positif untuk dilaksanakan karena merupakan suatu komitmen berkelanjutan oleh dunia usaha untuk bertindak etis dan memberikan kontribusi kepada pengembangan ekonomi dari komunitas setempat ataupun masyarakat luas, bersamaan dengan peningkatan taraf hidup pekerjanya.
Loen (2018) berdasarkan hasil penelitiannya mengungkapkan bahwa MFCA berpengaruh positif terhadap sustainable development dan resouce efficiency memperkuat MFCA terhadap sustainable development.

\section{Kerangka Berfikir}

Perusahaan harus mampu mengelola biaya lingkungan agar dapat menjadi industri yang ramah lingkungan. Pengelolaan biaya lingkungan ini dikenal dengan istilah ecoefesiency. Walaupun penerapan green accounting seolaholah dapat menambah beban perusahaan karena harus menyisihkan dana untuk biaya lingkungan namun pada akhirnya penerapan green accounting dapat memberikan keuntungan kepada perusahaan . Dalam penelitian ini peneliti akan meneliti pengaruh green accounting terhadap MFCA serta resource efficiency sebagai variabel moderating terhadap keberlangsungan usaha (studi kasus pada industri hijau yang listing di jakarta islamic index).

\section{METODE PENELITIAN}

Penelitian ini merupakan penelitian kuantitatif dimana dalam penelitian kuantitatif tidak terlalu menitikberatkan pada kedalaman data, yang penting dapat merekam data sebanyak banyaknya dari populasi yang luas. Walaupun populasi penelitian besar, tetapi dengan mudah dapat dianalisis, baik melalui rumus - rumus statistik maupun komputer. Jadi pemecahan masalahnya di dominasi oleh statistik ( Masyhuri, 2008). Studi Pustaka : dari artikel, jurnal, buku, dan penelitian terdahulu.Studi Dokumenter : dengan mengumpulkan data sekunder yang 
berupa data data laporan keuangan tahunan perusahaan yang industri hijau listing di jakarta islamic index periode 2016-2019 yang diperoleh dari laporan tahuunan idx.

Teknik sampling yang digunakan dalam penelitian ini bersifat purposive sampling atau sampling bertujuan. Dalam hal ini peneliti memilih informan yang dianggap mengetahui permasalahan dan dapat dipercaya untuk menjadi sumber data yang memiliki kebenaran dan pengetahuan yang mendalam. Namun demikian, informan yang dipilih dapat menunjukkan informan lain yang dipandang lebih tahu. Maka pilihan informan dapat berkembang sesuai dengan kebutuhan dan kemantapan peneliti dalam memperoleh data (Sutopo, 2002: 56). Teknik purposive sampling juga digunakan atas dasar teknik ini dipandang mampu menangkap kedalaman data dalam menghadapi realitas jamak dan tidak dimaksudkan untuk membuat generalisasi tetapi untuk kedalaman penelitian dalam konteks tertentu. Adapun kriteria tersebut antara lain:

1. Perusahaan kategori industri hijau yang terdaftar pada jakarta islamic index yakni dari tahun 2016 sampai 2019.

2. Perusahaan kategori industri hijau yang menerbitkan laporan keuangan yang lengkap selama tahun pengamatan, yakni dari tahun 2016 sampai 2019.

3. Perusahaan kategori industri hijau di jakarta islamic index yang menggunakan mata uang rupiah sebagai mata uang pelaporan.

4. Perusahaan kategori industri hijau di jakarta islamic index yang selama tahun pengamatan yakni, 2016-2019 mempunyai biaya-biya produksi dan luas area pabrik.
5. Perusahaan tidak dikeluarkan dari bursa (delisted) pada periode sampel.

$\begin{array}{llrr}\text { Menurut Lexy } & \text { J.Moleong (2000), } \\ \text { analisa data adalah proses } \\ \text { mengorganisasikan dan mengurutkan }\end{array}$ data ke dalam pola, kategori, dan satuan uraian dasar sehingga dapat ditemukan tema dan dapat dirumuskan hipotesis kerja, seperti yang disarankan oleh data. Teknik analisa data merupakan suatu langkah yang paling menentukan dari suatu penelitian, karena analisa data berfungsi untuk menyimpulkan hasil penelitian.

\section{Uji Hipotesis}

Penelitian ini akan menggunakan Software SPSS dengan analisis Analisis Regresi Berganda, Uji Koefiseien Determinasi (Uji R2), Uji Signifikansi Simultan (Uji Statistik F).

\section{HASIL PENELITIAN DAN PEMBAHASAN}

Data yang dibutuhkan dalam penelitian ini adalah laporan keuangan bank syariah sudah dan masih terdaftar di Jakarta Islamic Index selama periode tahun 2016 sampai 2019. Dengan menggunakan alat analisis spss versi 17.Populasi perusahaan yang berpredikat green industry dan masih terdaftar di JII berjumlah 30 perusahaan. Pengambilan sampel dalam penelitian ini dilakukan dengan menggunakan teknik purposive sampling yaitu pengambilan sampel berdasarkan kriteria tertentu.

Kriteria pengambilan sampel pada penelitian ini diambil setelah memenuhi beberapa kriteria sebagai berikut: Perusahaan yang mendapat penghargaan green industry listing dan terdaftar di Jakarta Islamic Index Periode 2016 - 
41 | Pengaruh Green Accounting Terhadap Mfca Dalam Meningkatkan Keberlangsungan Usaha Serta Resource Efficiency Sebagai Variabel Moderating (Studi Kasus Pada Perusahaan Peraih Penghargaan Hijau Yang Listing Di Jakarta Islamic Index)

2019, Perusahaan yang mendapat penghargaan green industry yang menyajikan laporan keuangan secara lengkap pada periode 2016 2019,Perusahaan yang mendapat penghargaan green industry yang menyajikan secara jelas biaya produksi, luas atau area pabrik, nilai produksi, green accounting, dan resources efficiency, Perusahaan yang mendapat penghargaan green industry di Jakarta Islamic Index yang melaporkan secara konsisten pada periode Januari 2016 Desember 2019.Berdasarkan kriteria yang ditentukan terdapat 30 perusahaan yang datanya sesuai dengan kebutuhan penelitian ini.

Hasil statistik data variabelvariabel yang digunakan dalam penelitian ini dan telah dilakukan pengolahan data adalah deskripsi analisis data yang akan berdasarkan minimum, maximum, mean dan standard deviasi adalah sebagai berikut:

1. Keberlangsungan usaha $(\mathrm{Y})$

Dari tabel stastistik di atas dapat diketahui bahwa nilai minmum keberlangsungan usaha sebesar 1 dan nilai maksimum 5. Hasil tersebut menunjukkan besarnya keberlangsungan usaha yang menjadi sampel penelitian ini berkisar antara 1 sampai 5 dengan rata-rata 2,59 pada standar deviasi 0,993. Nilai rata - rata (mean) lebih kecil dari standar deviasi yaitu $0,993<2,59$ berarti bahwa sebaran nilai keberlangsungan usaha perusahaan yang memperoleh penghargaan green industry di JII tidak baik.

2. Biaya Produksi (X1)

Dari tabel stastistik di atas dapat diketahui bahwa nilai biaya produksi sebesar 3,00 dan nilai maksimum 6,00. Hasil tersebut menunjukkan besarnya biaya produksi perusahaan yang menjadi sampel penelitian ini berkisar antara 3,00 sampai 6,00 dengan ratarata 3,73 pada standar deviasi 0,920 . Nilai rata - rata (mean) lebih besar dari standar deviasi yaitu 3,73>0,920 berarti bahwa sebaran nilai biaya produksi perusahaan cukup baik.

3. Luas area pabrik produksi (X2)

Dari tabel stastistik di atas dapat diketahui bahwa nilai minimum luas area pabrik produksi sebesar 1,00 dan nilai maksimum 5. Hasil tersebut menunjukkan besarnya luas area pabrik produksi yang menjadi sampel penelitian ini berkisar 1 ,oo dan 5 dengan rata-rata 2,55 pada standar deviasi 0,919 . Nilai rata - rata (mean) lebih besar dari standar deviasi yaitu 2,55 > 0,919 berarti bahwa sebaran nilai luas area pabrik produksi baik.

4. Hasil atau nilai produksi $\left(\mathrm{X}_{3}\right)$

Dari tabel stastistik di atas dapat diketahui bahwa nilai minimum hasil atau nilai nilai produksi perusahaan sebesar 1 dan nilai maksimum 5. Hasil tersebut menunjukkan besarnya hasil atau nilai produksi perusahaan yang berpredikat green industry di JII yang menjadi sampel penelitian ini berkisar 1 dan 5 dengan rata-rata 2,54 pada standar deviasi 1,137. Nilai rata - rata (mean) lebih besar dari standar deviasi yaitu 2,54 > 1,137 berarti bahwa sebaran hasil atau nilai produksi cukup baik.

5. Green Accounting (X4)

Dari tabel stastistik di atas dapat diketahui bahwa nilai minimum hasil atau nilai produksi perusahaan sebesar 1 dan nilai maksimum

6. Hasil tersebut menunjukkan besarnya nilai green accounting perusahaan yang berpredikat green industry di JII yang menjadi sampel penelitian ini berkisar 1 dan 6 dengan rata-rata 2,81 pada 
standar deviasi 1,145. Nilai rata - rata (mean) lebih besar dari standar deviasi yaitu 2,81 > 1,145 berarti bahwa sebaran nilai green accounting cukup baik.

Tabel 1. Min, Max, Mean dan Standar Deviasi

\begin{tabular}{|l|l|l|l|r|r|}
\hline & N & MIN & MAX & \multicolumn{1}{|l|}{ MEAN } & \multicolumn{2}{|l|}{$\begin{array}{l}\text { STD. } \\
\text { DEVIASION }\end{array}$} \\
\hline biaya produksi & 90 & 3 & 6 & 3.73 & .920 \\
$\begin{array}{l}\text { luas area pabrik } \\
\text { produksi } \\
\text { hasil atau nilai } \\
\text { produksi } \\
\text { green accounting }\end{array}$ & 90 & 1 & 5 & 2.55 & .919 \\
\cline { 2 - 4 } & 90 & 1 & 5 & 2.54 & 1.137 \\
\hline
\end{tabular}

Sumber: Data Diolah oleh Peneliti

\section{Normalitas}

Uji normalitas bertujuan menguji apakah dalam model regresi, variabel dependen dan variabel independen keduanya mempunyai distribusi normal atau tidak.Model regresi yang baik adalah memiliki distribusi normal atau mendekati normal.Untuk mendeteksi normalitas dapat dilakukan dengan uji statistic. Tes statistic yang digunakan antara lain analisis grafik histogram, normal probability plots dan kolmogorov - smirnov test (Imam Ghozali, 2001).

Hasil pengujian normalitas data dengan uji kolmogorov - Smirnov dapat dilihat pada tabel berikut ini.

Hasil sampel menunjukkan bahwa nilai kolmogrov - smirnov menunjukkan nilai 1,563 dengan tingkat signifikansi sebesar 0,015. karena hasil kolmogrov smirnov menunjukkan signifikansi data 0,05 maka hal tersebut menunjukkan data residual terdistribusi secara normal. Pengujian normalitas data adalah pengujian tentang kenormalan distribusi data. Uji normalitas bertujuan menguji apakah dalam model regresi memiliki distribusi normal. Uji normalitas diuji dengan menggunakan uji Kolmogorov Smirnov dengan membuat hipotesis.

Hipotes yang digunakan adalah:

Ho: Data residual berdistribusi normal

Ha: Data residual tidak berdistribusi normal

Hasil uji normalitas pada gambar dibawah dengan menggunakan normal probability plot yang membandingkan distribusi kumulatif dari distribusi normal. Normalitas dapat dideteksi dengan melihat penyebaran data (titik) pada sumbu diagonal dari grafik.

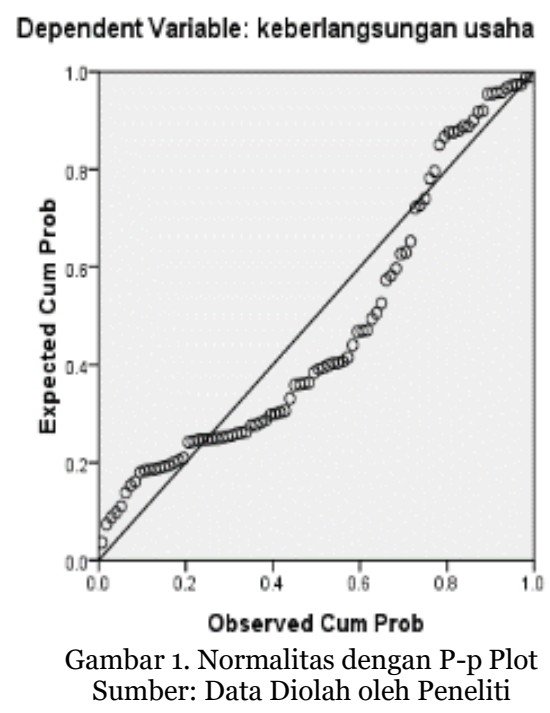

Tabel 2. Normalitas dengan Kolmogorov-Smirnov One-Sample Kolmogorov-Smirnov Test

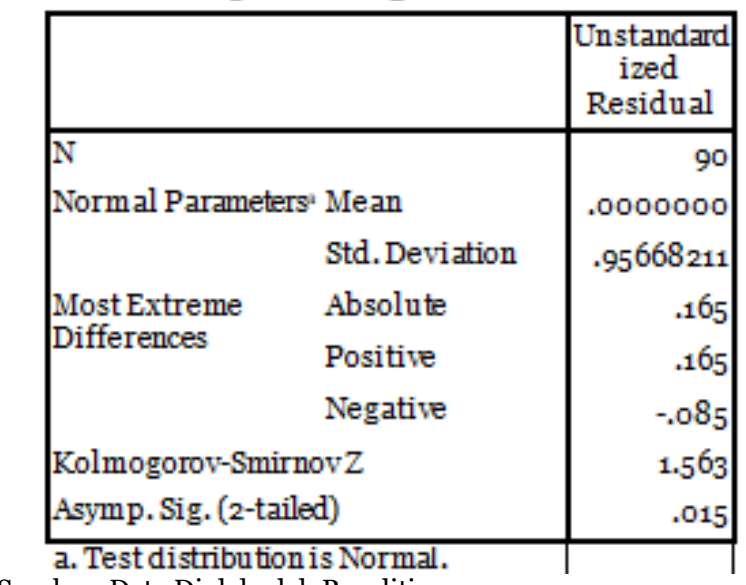

Sumber: Data Diolah oleh Peneliti 


\section{Uji Multikolinieritas}

Uji Multikolinieritas bertujuan untuk menguji apakah dalam model regresi ditemukan adanya korelasi antara variabel indepen (Ghozali, 2011: 105). Hasil yang ditunjukkan dalam output SPSS maka besarnya VIF dari empat variabel independen yang digunakan (biaya produksi, luas area pabrik, hasil atau nilai produksi, green accounting) dapat dilihat pada table 4.2 sebagai berikut:

Tabel 3. Uji Variance Inflation Factor (VIF)

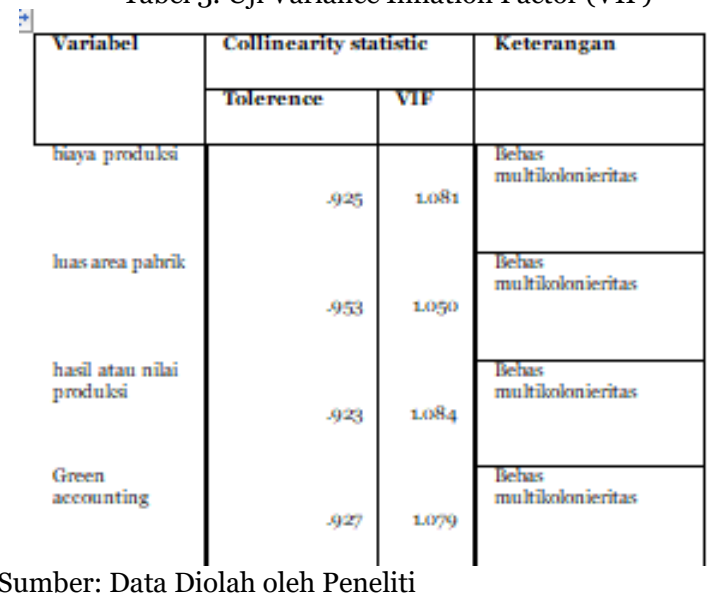

Hasil dari uji VIF pada table menunjukkan bahwa ketiga variabel independen tidak terjadi multikolonieritas karena nilai VIF < 10 dan TOL > 0,1. Hal ini dapat dilihat besarnya nilai tolerance untuk variabel biaya produksi, luas area pabrik,hasil atau nilai produksi, dan green accounting. Nilai tolerance semua variabel diatas 0,1. Sedangkan nilai VIF dari variabel biaya produksi,luas area pabrik,hasil atau nilai produksi dan green accounting, nilai VIF semua variabel dibawah 10. Dengan demikian keempat variabel independen (biaya produksi, luas area pabrik, hasil atau nilai produksi dan green accounting) dapat digunakan untuk memprediksi keberlangsungan usaha selama periode pengamatan.

\section{Uji Heteroskedastisitas}

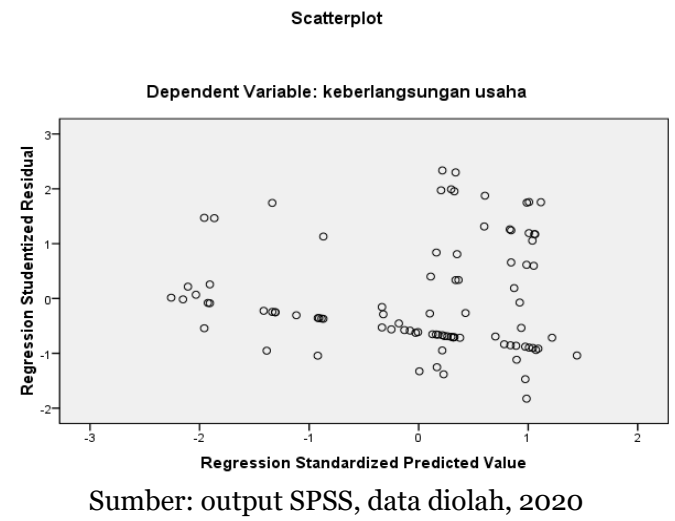

Grafik scatter plots pada kedua model regresi memperlihatkan bahwa titik - titik pada grafik tidak membentuk bisa membentuk pola tertentu yang jelas, dimana titik - titik menyebar di atas dan di bawah angka o pada sumbu Y, sehingga grafik tersebut tidak bias dibaca dengan jelas. Hasil ini memperlihatkan bahwa tidak terjadi heteroskedasitas.

\section{Uji Autokorelasi}

Tabel 4. Uji Autokorelasi

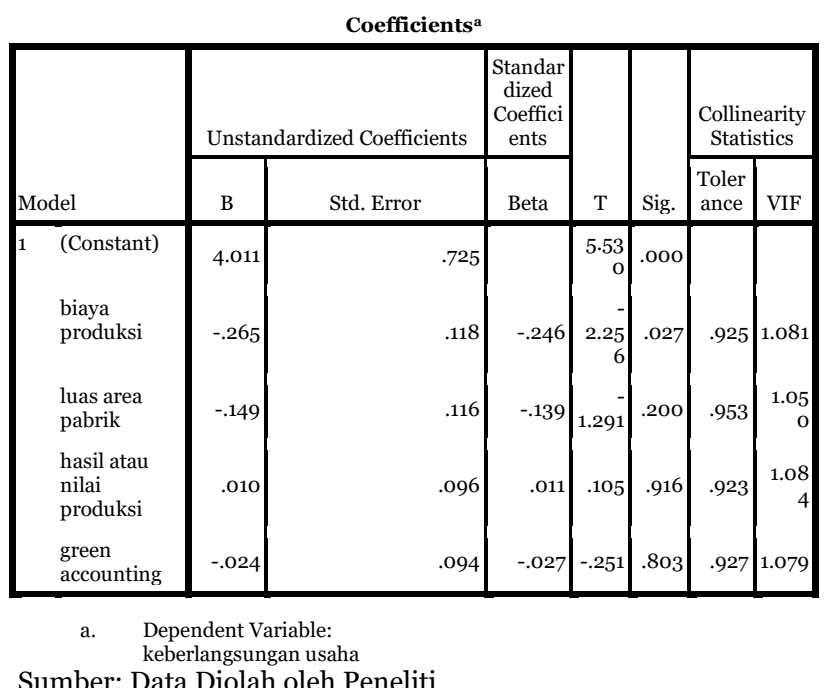




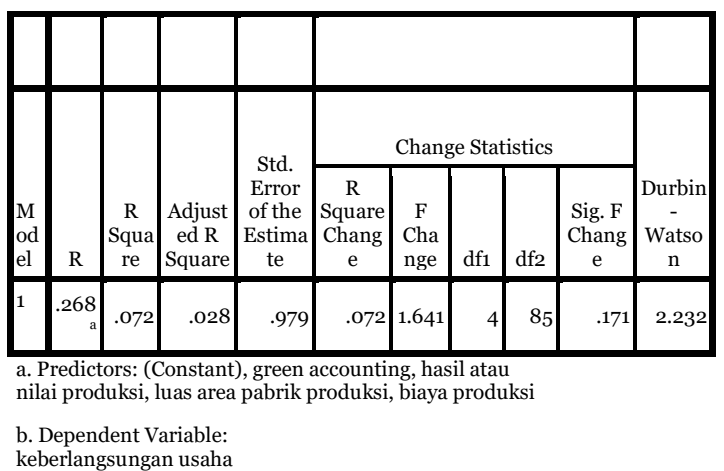

Tabel 5. Dublin Watson

Sumber: data sekunder yang diolah 2020

Berdasarkan kriteria pengujian di atas, nilai DW sebesar 2,232 nilai ini akan diperbandingkan dengan nilai DW tabel dengan menggunakan derajat kepercayaan 10 persen untuk n sejumlah 90 dan jumlah variabel bebas 4 . Nilai DW tabel sebagai berikut: batas atas $d u=1,46$ dan batas bawah $(\mathrm{dl})=0,59$. Oleh karena nilai DW lebih besar dari batas atas dan (du) dan lebih kecil dari $4-\mathrm{du}=4-1,46=$ 2,54 sehingga tidak ada masalah autokorelasi.

\section{Hasil Pengujian Hipotesis}

Hipotesis pertama pada penelitian akan diuji parsial (Uji-t) untuk mengetahui apakah variabel bebas individu berpengaruh terhadap variabel terikat. Uji model akan diuji menggunakan uji simultan (Uji F) untuk mengetahui pengaruh variabel bebas terhadap variabel terikat secara simultan. Sebelum melakukan uji-t dan uji F maka dilakukan pengujian uji regresi linier berganda sebagai berikut:

\section{Uji Regresi Linier Berganda}

$\mathrm{Y}=\alpha+\left(\beta_{1}\right.$-biaya produksi $)+\left(\beta_{2} \cdot\right.$ luas area pabrik $)+(\beta 3$ hasil atau nilai produksi $)+(\beta 4$.green accounting $)+e$ $\mathrm{Y}=3,843+-2,48$ biaya produksi $+-0,141$ luas area pabrik $+0,027$ hasil atau nilai produksi $+-0,14$ green accounting $+\mathrm{e}$
Pengolahan data dilakukan dengan menggunakan bantuan Software SPSS 21. Hasil yang diperoleh selanjutnya akan diuji kemaknaan model tersebut secara simultan dan secara parsial. Berdasarkan data diperoleh hasil regresi linier berganda sebagai berikut:

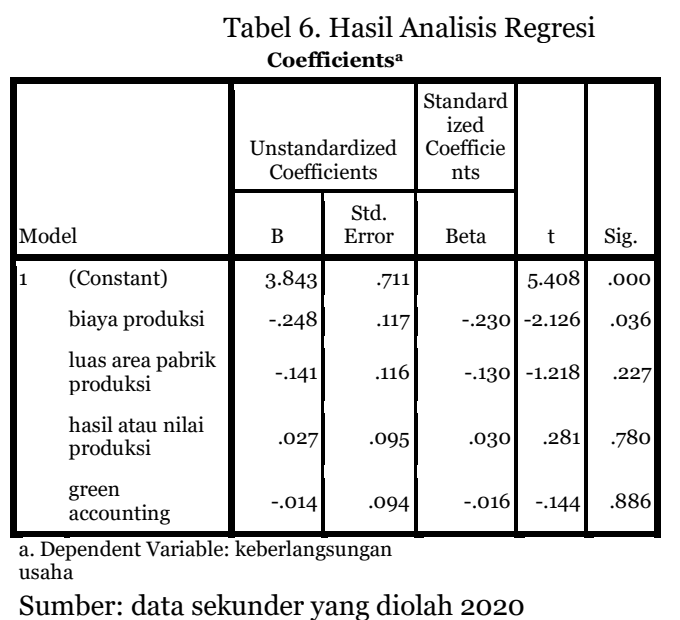

Koefisien-koefisien persamaan regresi linier berganda dapat diartikan sebagai berikut:

1. Konstanta (a) sebesar 3,843 mempunyai arti apabila semua variabel independen sama dengan nol maka keberlangsungan perusahaan bernilai sebesar 3,843.

2. Koefisien regresi biaya produksi sebesar -0,248 artinya setiap biaya produksi sebesar satuan menurunkan keberlangsungan perusahaan sebesar 0,248 dengan asumsi faktor - faktor yang lain tetap atau ceteris paribus.

3. Koefisien regresi luas area pabrik o,141 mempunyai arti setiap kenaikan luas area pabrik sebesar 1 satuan akan menurunkan keberlangsungan perusahaan sebesar -0,141 satuan dengan asumsi faktor - faktor yang lain tetap atau ceteris paribus.

4. Koefisien regresi hasil produksi sebesar 0,027 artinya setiap kenaikan hasil produksi sebesar 1 satuan menaikkan keberlangsungan perusahaan sebesar 0,027 satuan dengan asumsi faktor - 
faktor yang lain tetap atau ceteris paribus.

\section{Uji Parsial (Uji-t)}

Uji statistik $t$ pada dasarnya menunjukkan seberapa jauh pengaruh satu variabel penjelas/independen secara individual dalam menerangkan variasi variabel dependen (Ghozali, 2011).

Koefisien regresi digunakan untuk mengetahui pengaruh variabel biaya produksi, luas area pabrik, hasil produksi dan green accounting secara parsial terhadap keberlangsungan usaha.

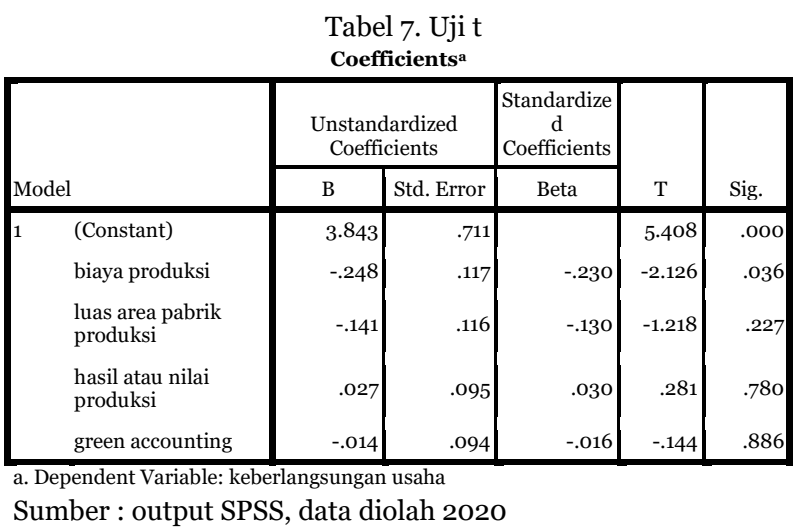

Variabel biaya produksi, luas area pabrik produksi, hasil atau nilai produksi dan green accounting. Hasil pengujian pengaruh variabel independen terhadap variabel dependennya sebagai berikut:

Pengujian hipotesis pertama

Ha1: MFCA (biaya produksi) berpengaruh dalam meningkatkan keberlangsungan perusahaan.

Berdasarkan hasil uji regresi linier berganda diperoleh nilai koefisien regresi untuk sebesar - 0,245. Hal ini menunjukkan bahwa hubungan antara MFCA (biaya produksi) terhadap keberlangsungan usaha adalah tidak searah. Variabel MFCA (biaya produksi) (X1) mempunyai t hitung sebesar $-2,126$ dengan signifikansi sebesar 0,036. Nilai signifikansi $t>0,05$ maka dapat disimpulkan MFCA (biaya produksi) tidak berpengaruh terhadap keberlangsungan perusahaan sehingga hipotesis pertama ditolak.Ini bertentangan dengan penelitian yang dilakukan oleh Wahyudin (2017) dalam penelitiannya mengungkapkan bahwa semakin banyak biaya produksi yang dikeluarkan perusahaan nantinya akan menyebabkan MFCA (biaya produksi) akan berpengaruh terhadap keberlangsungan perusahaan.

Pengujian hipotesis kedua Ha2: MFCA (luas area pabrik produksi) berpengaruh dalam meningkatkan keberlangsungan perusahaan

Berdasarkan hasil uji regresi linier berganda diperoleh nilai koefisien regresi untuk sebesar -0,141. Hal ini menunjukkan bahwa hubungan antara MFCA (luas area pabrik produksi) terhadap keberlangsungan usaha adalah tidak searah. Variabel MFCA (luas area pabrik) (X2) mempunyai t hitung sebesar $-1,218$ dengan signifikansi sebesar 0,227. Nilai signifikansi $t>0,05$ maka dapat disimpulkan ukuran MFCA (luas area pabrik produksi) tidak berpengaruh terhadap keberlangsungan usaha sehingga hipotesis kedua ditolak. Ini sama dengan penelitian yang dilakukan oleh wahyudin (2017) Dengan demikian luas area produksi tidak berpengaruh dan tidak signifikan terhadap keberlangsungan perusahaan. Hal ini disebabkan adanya setiap peningkatan luas area pabrik produksi tidak menjamin meningkatkan keberlangsungan suatu perusahaan. Artinya, semakin luas area pabrik perusahaan yang dimiliki maka tidak meningkatkan keberlangsungan dalam 
perusahaan. Luasnya lahan dapat mengakibatkan upaya melakukan tindakan yang mengarah pada segi efisiensi akan berkurang disebabkan lemahnya faktor produksi ataupun tidak efisiensi biayabiaya. produksi yang dikeluarkan perusahaan, terbatasnya persediaan tenaga kerja ataupun faktor lingkungan perusahaan. Penelitian Ambarita dan Kartika (2015) menunjukkan bahwa semakin besar luas lahan maka semakin besar produktivitas yang di hasilkan. Tata letak pabrik adalah suatu landasan utama dalam dunia industri. Plant layout atau facilities layout didefinisikan sebagai tata cara pengaturan fasilitasfasilitas pabrik guna menunjang kelancaran proses produksi, jarak material handling dalam area produksi akan mempengaruhi lintasan dan waktu proses dari produksi (Pratiwi, et al., 2012).

Pengujian Hipotesis Ketiga

H3: MFCA (Hasil atau Nilai Produksi) Berpengaruh dalam

Meningkatkan Keberlangsungan usaha .

Berdasarkan hasil uji regresi linier berganda diperoleh nilai koefisien regresi untuk MFCA (Hasil atau Nilai Produksi) sebesar 0,027. Hal ini menunjukkan bahwa hubungan antara MFCA (hasil atau nilai produksi) adalah tidak searah. Variabel MFCA (hasil atau nilai produksi) (X3) mempunyai t hitung sebesar 0,281 dengan signifikansi sebesar 0,780. Nilai signifikansi $t$ MFCA (hasil atau nilai produksi) > 0,05 maka dapat disimpulkan MFCA (hasil atau nilai produksi berpengaruh negatif dan signifikan terhadap keberlangsungan usaha sehingga hipotesis ketiga ditolak. Hal ini berbeda dengan penelitian yang dilakukan oleh Penelitian wahyudin (2017) menemukan bahwa hasil atau nilai produksi berpengaruh positif dan signifikan terhadap keberlangsungan perusahaan. Hasil pengujian ini juga berbeda dengan penelitian Sudarsono dalam Ningsih dan Indrajaya (2015), yang mengatakan hasil atau nilai produksi berpengaruh positif terhadap keberlangsungan usaha, nilai produksi merupakan seluruh tingkat suatu produksi yang berdasarkan atas harga jual produk-produk tersebut menggunakan faktor-faktor produksi yang dimiliki oleh perusahaan dalam satu periode yang pada akhirnya akan dijual kepada pembeli. Hasil produksi kapasitas produksinya.

Pengujian Hipotesis keempat

$\mathrm{H}_{4}$ : Green accounting berpengaruh positif terhadap keberlangsungan usaha

Berdasarkan pada tabel hasil uji regresi linier berganda diperoleh nilai koefisien regresi untuk green accounting sebesar -0,014. Hal ini menunjukkan bahwa hubungan antara green accounting dengan keberlangsungan usaha adalah tidak searah. Variabel green accounting (X4) mempunyai t hitung sebesar -0,144 dengan signifikansi sebesar o,886. Nilai signifikansi $t$ green accounting > 0,05 maka dapat disimpulkan green accounting berpengaruh negatif dan signifikan terhadap keberlangsungan usaha sehingga hipotesis keempat ditolak. Hal ini berbeda dengan penelitian yang dilakukan oleh Penelitian Loen (2018) menemukan bahwa green accounting berpengaruh positif dan signifikan terhadap keberlangsungan perusahaan.

\section{Hasil Uji Regresi Moderasi Nilai Selisih Mutlak}




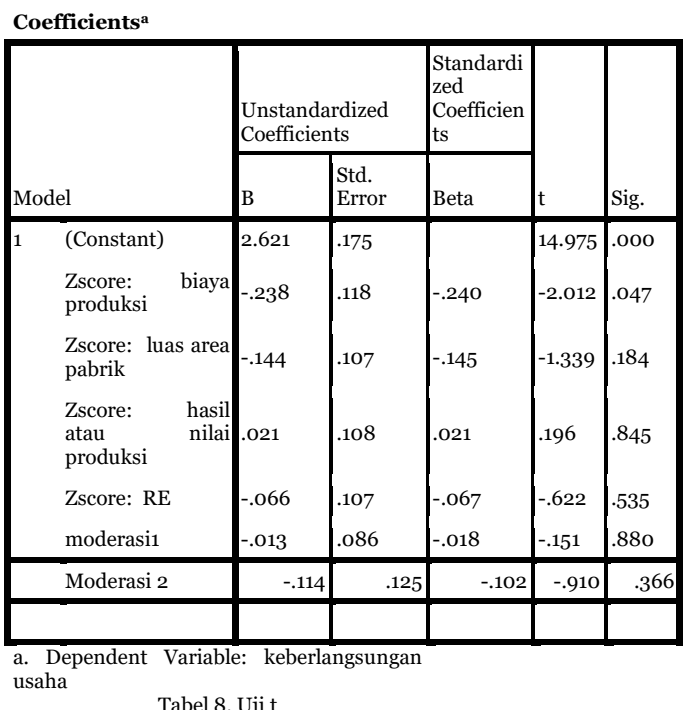

Pengujian Hipotesis kelima Menunjukkan bahwa variabel resource efficiency menunjukkan bahwa variabel moderating X1_M tidak signifikan dengan nilai koefisien regresi (standardized coefficients) sebesar 0,013 dan angka signifikansi sebesar o,880 (lebih besar dario,05).

\section{Variabel}

memoderasi

MFCA

resouce efficiency terhadap berlangsungan perusahaan $_{5}$ ditolak). Justifikasi atas tidak adanya interaksi atau moderasi $R E$ tidak memoderasi MFCA terhadap keberlangsungan perusahaan adalah bahwa Resource Efficiency dalam perusahaan tersebut tidak mampu memoderasi material flow cost accounting terhadap keberlangsungan perusahaan. Hal ini tersebut tampak bahwa $\mathrm{X}_{5} \_\mathrm{M}$ dengan tingkat signifikansi $0,880<0,05$.

Pengujian Hipotesis keenam

Menunjukkan bahwa variabel resource efficiency menunjukkan bahwa variabel moderating $\mathrm{X} 2 \_\mathrm{M}$ tidak signifikan dengan nilai koefisien regresi (standardized coefficients) sebesar -0,114 dan angka signifikansi sebesar 0,366 (lebih besar dario,05). Variabel green accounting tidak memoderasi resouce efficiency terhadap berlangsungan perusahaan (H6 ditolak). Justifikasi atas tidak adanya interaksi atau moderasi green accounting tidak memoderasi resource efficiency terhadap keberlangsungan perusahaan adalah bahwa bahwa green accounting dalam perusahaan tersebut tidak mampu memoderasi material flow cost accounting terhadap keberlangsungan perusahaan. Hal ini tersebut tampak bahwa X6_M dengan

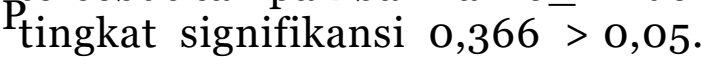
Hasil hipotesis tampak pada tabel dibawah

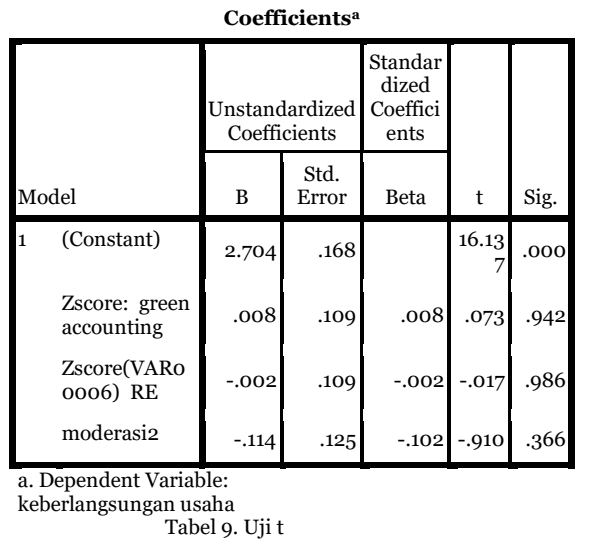

Menunjukkan bahwa variabel resource efficiency tmampu memoderasi implikasi green accounting terhadap keberlangsungan perusahaan. Hal ini tersebut tampak bahwa X6_M dengan tingkat signifikansi $0,366<0,05$.

\section{Uji Signifikansi Simultan (Uji F)}

Uji F digunakan untuk menguji signifikansi model regresi. Tujuan dari uji F ini adalah untuk membuktikan secara statistik bahwa keseluruhan koefisien regresi yang digunakan dalam analisis ini 
signifikan. Apabila nilai signifikansi $\mathrm{F}$ lebih kecil dari 0,05 maka model regresi signifikan secara statistik. Bila nilai $\mathrm{F}$ hitung lebih besar daripada nilai $\mathrm{F}$ tabel, maka Ho ditolak dan menerima Ha. (Ghozali, 2011).

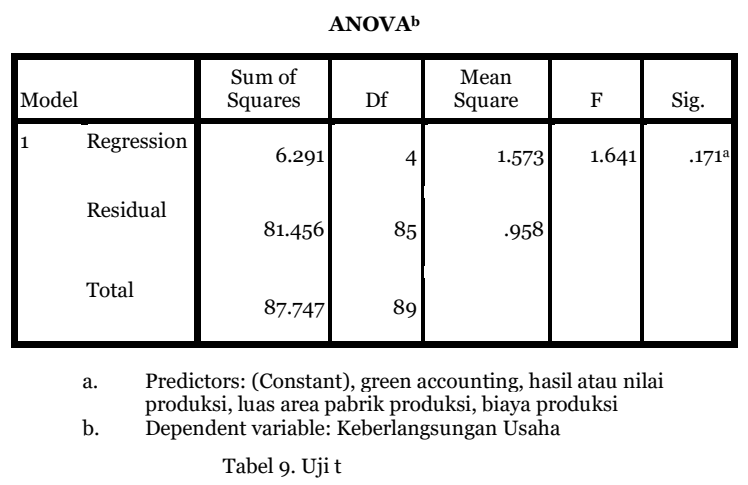

Sumber: Data sekunder yang diolah 2020

Pengujian signifikansi pengaruh variabel dewan komisaris, dewan pembina syariah dan profitabilitas secara simultan dapat dilihat pada tabel 4.6 uji simultan, bahwa nilai $\mathrm{F}$ hitung sebesar 1,178 dengan signifikansi sebesar 0,171. Nilai signifikansi $0,171>0,05$ menunjukkan bahwa variabel green accounting,hasil atau nilai produksi, luas area pabrik dan biaya produksi tidak berpengaruh terhadap keberlangsungan usaha.

\section{Koefisien Determinasi (adjusted $R$ square)}

Koefisien determinasi atau adjusted $\mathrm{R}^{2}$ dapat dilihat pada tabel berikut:

Tabel 10. Adjusted R Square

Model Summary ${ }^{\mathrm{b}}$

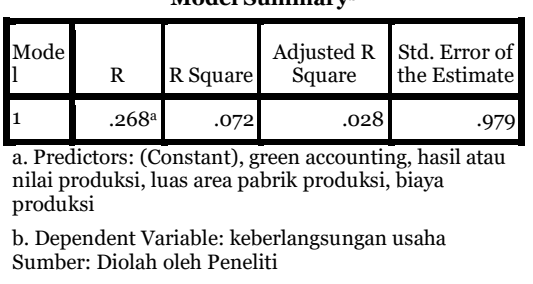

Berdasarkan table dapat dilihat angka koefisien determinasi ( Adjusted $\mathrm{R}$ square) sebesar 0,72 atau $72 \%$. Hal ini menunjukkan bahwa variabel independen berupa green accounting, hasil atau nilai produksi, luas area pabrik dan biaya produksi dapat menjelaskan variabel dependen (keberlangsungan usaha) sebesar 0,72 sisanya 28\% dijelaskan oleh variabel - variabel lain di luar penelitian ini.

\section{KESIMPULAN}

Dari hasil analisis dan pembahasan yang telah diuraikan penulis menarik beberapa kesimpulan sebagai berikut,terdapat pengaruh positif Material Flow Cost Acconting MFCA terhadap keberlangsungan usaha bahwa dari variabel green accounting,hasil atau nilai produksi, luas area pabrik dan biaya produksi tidak berpengaruh terhadap keberlangsungan usaha. Sedangkan Resource Efficiency dalam perusahaan tersebut tidak mampu memoderasi material flow cost accounting terhadap keberlangsungan perusahaan. Hal ini bisa dipengaruhi dari masih adanya penggunaan material dan energi yang kurang efisien, kurangnya pengelolaan limbah secara efektif dan belum bisa mengurangi biaya keuangan perusahaan secara efisien dan efektif. Green accounting tidak memoderasi dampak dalam meningkatkan Resource efficincy terhadap keberlangsungan perusahaan. Pengungkapan green accounting dalam perusahaan yang tergabung dalam jakarta islamic index yang meraih penghargaan industri hijau sifatnya hanya suka rela.

\section{Keterbatan Penelitian}

Dengan adanya penelitian ini
diharapkan mampu menjadi acuan
perusahaan yang meraih penghargaan


industri hijau yang tergabung di jakarta islamic index untuk meningkatkan pengelolaan dan pelestarian lingkungan. Material flow cost accounting atau MFCA sangat bermanfaat bagi perusahaan untuk meningkatkan keberlangsungan perusahaan khususnya dalam mengurangi limbah, penggunaan material dan energi yang kurang efisien dan mengurangi biaya keuangan perusahaan. Bagi penelitian selanjutnya diharapkan dapat mengamati variabel lainnya dan lebih mengembangkan penelitian tentang MFCA karena masih kurang dalam dunia penelitian terkait MFCA dengan variabel-variabel lainnya

\section{DAFTAR PUSTAKA}

Bare, J. C. 2011. Five Key Elements for Enviromental Sustainable Progress.International Journal for Sustainable Innovations 1(1): 9198.

Burhany, D. I. 2014. Pengaruh Implementasi Akuntansi Lingkungan terhadap Kinerja Lingkungan dan Pengungkapan Informasi Lingkungan (Studi pada Perusahaan Pertambangan Umum yang Mengikuti PROPER Periode
2008-2009). Indonesian Journal of Economics and Business, 1(2): 257270

Loen 2018, “ penerapan green accounting dan material flow cost accounting terhadap sustainable development" jurnal akuntansi dan bisnis krisnadwipayana

Soehardi, S., \& Untari, D. T. (2020). The Effect of Covid-19 Pandemic on Hotel Employees, Hotel Occopancy Rates and Hotel Tax Income in Jakarta, Indonesia. Systematic Reviews in Pharmacy, 11(12), 964-972. https://doi.org/10.31838/srp.2020.5. 138

Wahyudin, hernawati 2020 "efek green accounting terhadap material flow cost accountaing dalam meningkatkan keberlangsungan perusahaan." Ekuitas jurnal ekonomi dan keuangan.

Yohannes M supadi 2018 “ Pengaruh Kinerja Lingkungan Dan CSR Disclosure Pada Kinerja Keuangan Sektor Pertambangan”, e- journal ekonomi bisnis universitas udayana. 